March 2006

\title{
Salvaging "Academic Disaster Areas": The Black College Response to Christopher Jencks and David Riesman's 1967 Harvard Educational Review Article
}

Marybeth Gasman

University of Pennsylvania, mgasman@gse.upenn.edu

Follow this and additional works at: https://repository.upenn.edu/gse_pubs

\section{Recommended Citation}

Gasman, M. (2006). Salvaging "Academic Disaster Areas": The Black College Response to Christopher Jencks and David Riesman's 1967 Harvard Educational Review Article. Retrieved from

https://repository.upenn.edu/gse_pubs/12

Copyright The Ohio State University. Reprinted from Journal of Higher Education, Volume 77, Issue 2, March/April 2006, pages 317-352. This material is posted here with permission of the Ohio State University Press. Content may not be copied or emailed to multiple sites or posted to a listserv or website without the copyright holder's written permission. However, users may print, download, or email articles for individual use.

This paper is posted at ScholarlyCommons. https://repository.upenn.edu/gse_pubs/12

For more information, please contact repository@pobox.upenn.edu. 


\title{
Salvaging "Academic Disaster Areas": The Black College Response to Christopher Jencks and David Riesman's 1967 Harvard Educational Review Article
}

\author{
Abstract \\ During my junior year at Grambling College, the campus was roiled by the release of an article in Harvard \\ Educational Review. [One of the articles] launched a broadside attack against Black colleges essentially \\ questioning whether these hard-fought for institutions deserved to exist. The article's publication caused \\ the handful of whites on the faculty to become noticeably uncomfortable and regrettably led some of the \\ colleagues and students to question their fealty to Grambling. (Schexnider, 2003, 128)

\section{Comments} \\ Copyright The Ohio State University. Reprinted from Journal of Higher Education, Volume 77, Issue 2, \\ March/April 2006, pages 317-352. This material is posted here with permission of the Ohio State \\ University Press. Content may not be copied or emailed to multiple sites or posted to a listserv or website \\ without the copyright holder's written permission. However, users may print, download, or email articles \\ for individual use.
}




\title{
Salvaging "Academic Disaster Areas": The Black College Response to Christopher Jencks and David Riesman's 1967 Harvard Educational Review Article
}

\begin{abstract}
During my junior year at Grambling College, the campus was roiled by the release of an article in Harvard Educational Review. [One of the articles] launched a broadside attack against Black colleges essentially questioning whether these hard-fought for institutions deserved to exist. The article's publication caused the handful of whites on the faculty to become noticeably uncomfortable and regrettably led some of the colleagues and students to question their fealty to Grambling. (Schexnider, 2003, 128)
\end{abstract}

In 1967, the Harvard Educational Review published an article entitled "The American Negro College" by Christopher Jencks and David Riesman. Because of the prestige of the journal and the institutional affiliation of the authors (Harvard), the article received much attention-both in the academic community and in the popular press (Time, Newsweek, and The New York Times). It severely criticized Black colleges, describing them as "academic disaster areas." Within the Black community there was a sense of shock, dismay, and betrayal. ${ }^{1}$ This was evident in the formal responses to the Jencks and Riesman article, one by the United Negro College Fund (UNCF) and its member college presidents in the Harvard Educational Review in 1967, the other

Marybeth Gasman is an Assistant Professor of Higher Education in the Graduate School of Education at the University of Pennsylvania. Her research focuses on the history of historically Black colleges and philanthropy. In addition to the anonymous reviewers of the Journal of Higher Education, she would like to thank Wayne J. Urban, Katherine V. Sedgwick, J. Matthew Hartley, and Edward M. Epstein for their comments on previous drafts of this article. She is also grateful to the staffs at the Rockefeller Archive Center, the Robert Woodruff Library at the Atlanta University Center, and the Columbia University Oral History Collection for their assistance in acquiring historical resources for this article.

The Journal of Higher Education, Vol. 77, No. 2 (March/April 2006)

Copyright (@) 2006 by The Ohio State University 
in Black Colleges in America by Charles V. Willie and Ronald R. Edmonds nearly 10 years later. Although most academics interested in Black colleges are familiar with the more formal responses to the Jencks and Riesman article, very few are aware of the behind-the-scenes efforts of the UNCF and the Black intellectual community to rescue the reputation of Black colleges - efforts that are indicative of an increased sense of Black consciousness present in the United States during the 1960s.

Using archival sources and oral history interviews, I will show the strategic ways in which Black college leaders and the UNCF tried to salvage the image of Black colleges during the late 1960s and throughout the 1970s. I will explore the specific charges that the UNCF and its member college presidents levied against the work of Jencks and Riesman. These charges include lack of understanding of the Black college community, false institutional comparisons, dismissal of the contributions to Black leadership, use of anecdotal evidence, and lack of scientific rigor. I will also examine the Black intellectual response to the Harvard Educational Review article-in particular, Charles V. Willie's 1976 Harvard conference on Black colleges. Willie subsequently published a book dedicated to the topic, each chapter of which is an almost direct response to claims in the Jencks and Riesman article. Why were the conference and resulting book necessary? What did they accomplish? An examination of the Jencks and Riesman article and the resulting responses and events reveals a telling example of African American agency-agency that is indicative of a period that saw the rise of Black studies programs and the Black power movement. Although different in tenor from the Black consciousness movement thrust onto the scene by groups such as the Black Panthers and the Student Nonviolent Coordinating Council (SNCC), the approach of Black college leaders demonstrated a nascent sense of independence and assertiveness in advancing the agenda of Black education. Their story and, in particular, their fight on behalf of Black-run institutions broaden our understanding of Black consciousness during the Civil Rights period and beyond (Gurin \& Epps, 1975; Levine, 1978; Stewart, 1999).

\section{The Jencks and Riesman Article}

Jencks and Riesman's article on Black colleges was not the first study to assess the quality of education offered by these institutions. During the early to mid-20th century, several concerned parties began to question the kind of education taking place at Black colleges (John, 1920; Jones, 1969; Klein, 1969; Phelps-Stokes Fund, 1932; U.S. Office of Education, 1942). ${ }^{2}$ Foundations were interested in gauging the colleges' 
quality so that they could justify continued support. Black intellectuals such as W. E. B. Du Bois wanted to verify the existence and success of a liberal arts curriculum at these institutions (Du Bois, 1910). Although most constituents of Black colleges knew there were disparities between Black and White institutions in the type of education being offered, there was no "scientific" evidence that demonstrated these inequalities (Browning \& Williams, 1978). Among the most important of these studies was Earl J. McGrath's Carnegie-sponsored book, The Predominantly Negro Colleges and Universities in Transition, published in 1965. In preparing the study, McGrath was guided by the advice of both Stephen J. Wright and Frederick D. Patterson of the UNCF. He pointed out the weaknesses among Black colleges but set them in context, noting that many of the same conditions existed at predominantly White institutions (McGrath, 1965). Although McGrath's research was funded by the Carnegie Foundation, it received very little media attention.

By the mid-1960s, there were more than 100 Black colleges (as designated by the United States Office of Education). Over 100,000 students - just over half of all Black college students - attended these institutions (Jaffe, Adams, \& Meyers, 1968a). At the same time, the issue of integration was at the forefront of the nation's consciousness. With the passage of the Voting Rights Act of 1964 and the Civil Rights Act of 1965, the Civil Rights Movement had reached its peak. These national changes brought relief for many Americans but sparked anger for others, making relations between Blacks and Whites very tense. Terrible riots took place in the Watts area of Los Angeles and in several other cities throughout the country, and Malcolm X, the symbol of Black Nationalism, was assassinated. All of this led to a greater sense of Black consciousness on Black college campuses and to an upsurge of Black pride and increased willingness to challenge status quo race relations (Thompson, 1973). According to historian Joy Williamson,

[S]tudents at [Black colleges] across the South entered the Civil Rights Movement and inaugurated a period of sustained mass activism in 1960. Their brand of activism broke with the past and shifted civil rights agitation from the courts to the streets. Four students from North Carolina A\&T, a public [Black college], staged a sit-in at the local Woolworth's to protest segregation and discrimination in eating establishments. Other students in North Carolina followed their example, and soon students in other states conducted their own sit-ins. Shaw University, a private college in North Carolina, hosted a conference to organize the sit-in movement in April. The Student Non-violent Coordinating Committee (SNCC) grew out of the conference and enabled college students across the South to coordinate their activities. ... [Black college] students and interested others traveled to the deep South and provided voter education classes, transportation to registration and 
voting locations, and psychological sustenance to disenfranchised African Americans. (Williamson, 2003, p. 6)

According to Daniel Thompson, "Until the 1960s Black colleges . . . were regarded as [conservative and non-confrontational] in their respective communities. They scrupulously refrained from taking any active part in the disruption or embarrassment of the local White social system" (with some exceptions, of course). ${ }^{3}$ With greater activism on the part of their students, Black college leaders were forced to change their perspective and role in the greater White and Black communities (Thompson, 1973, p. 16).

Many of the nation's leading newspapers were running stories related to Black colleges. For example, in January 1966 The New York Times ran stories titled "Integrating the Negro Colleges," "Negro Colleges Recruit Whites," and "The Negro College Pleas for Donations." Curiously, national newspaper articles focused on integration of White institutions and the financial state of Black colleges, but ignored the changes taking place on Black college campuses. Jencks and Riesman used a similar approach - one that focused on the problems and virtually ignored the successes of Black colleges, their leaders, and their students - when they began their work in 1965 .

The Harvard-based authors started their research on Black colleges as part of a larger book project with chapters devoted to each of the major groups of academic institutions (later published as The Academic Revolution). Although quite young, Jencks was an editor for The New Republic, and Riesman, already considered an eminent sociologist, had recently authored The Lonely Crowd - which was on The New York Times bestseller list and is still considered one of the most influential books of the 20th century (C. Jencks, personal communication, September 30, 2003). Riesman also penned Constraint and Variety in American Education in 1956, which described a hierarchy among types of colleges and universities and the corresponding competition taking place within this hierarchy. Commenting on how they came to the idea for the article/chapter, and with a perspective that indicates a post-Brown bias against Black colleges (namely that integration made Black colleges obsolete), Jencks said,

David Riesman had visited a few Black colleges and I had visited one or two of them. And the logic of the book if you were writing it in the mid-1960s was that you needed to pay attention to these institutions. The United States was going to integrate white higher education so it would also need to do something about historically black colleges (C. Jencks, personal communication, September 30, 2003). 
Continuing its earlier interest in the state of Black colleges and higher education in general, the Carnegie Foundation provided funding to Jencks and Riesman (Jencks and Riesman, 1967a). In the "The American Negro College," Jencks and Riesman attempted to identify the problems faced by these institutions and made predictions for their future. ${ }^{4}$ Specifically, Jencks recalled, "The goal was to describe what was going on, to understand the evolution of these institutions, and to discover what kind of dilemmas they faced." Moreover, in a statement indicating that he had a sense of the importance of the Black college research, Jencks said, "[We aimed] to tell someone who knew nothing about Black colleges, which was about $97 \%$ of the population, how to be thinking about them" (C. Jencks, personal communication, September 30, 2003).

Jencks and Riesman's opening statements in the Harvard Educational Review article seemed to anticipate the racial conflict that the publication was likely to spur. The authors began with a caveat that justified the articles' harsh tone and preemptively dismissed charges of racism:

Few who write about the conditions of American Negro life can entirely escape the racist assumptions which are so much a part of American culture. This applies to Negroes as well as Whites. Nor can such writers escape the fact that oppression corrupts the oppressed as well as the oppressors. Many features of Negro life are extremely ugly, and are made no more beautiful by the knowledge that they are by-products of White prejudice. Since racists use such ugliness to justify continued segregation and paternalism, writers who provide them with ammunition are bound to look like racists to many readers. . . Nonetheless, it seems important to try to describe what we have seen as honestly as we can rather than trying to pretend that we have not seen it at all (Jencks \& Riesman, 1967a, p. 4). ${ }^{5}$

The Harvard sociologists' remarks resemble contemporary arguments against "political correctness" in academic speech-i.e., that scholars should not be obligated to adjust their research language to avoid denigrating the oppressed.

"The American Negro College" begins with an historical overview of the development of African American society in the United States and the subsequent need for and establishment of Black colleges. Jencks and Riesman did justice to the complicated political situation that Blacks faced during the early to mid-20th century, placing most of their emphasis on the gaps in income, education level, and employment status as compared to the majority community, including recent immigrant populations.

In their discussion of Black colleges and philanthropy's involvement in their establishment, the Harvard sociologists sided with conservative 
scholars and apologists for industrial philanthropy, noting that "Rather than assuming a Machiavellian plot to support 'Uncle Toms' like Booker T Washington against 'militants' like W. E. B. Du Bois, we would argue that the Northern whites who backed private colleges for Negroes were moved by genuinely philanthropic motives" (Jencks \& Riesman, 1967a, p. 16). Jencks and Riesman believed that Northern Whites saw no conflict between their own personal monetary gain and the gain of Blacks.

As the authors moved into a contemporary critique of Black colleges, they relied on several sources for their data: miscellaneous interviews with a few Black college faculty (Black, White, and Asian American faculty), surveys, statistical data, government documents, and published books and articles. In fact, Jencks and Riesman's explanation of their methodology was quite vague and fell short of the standards of most academic research-a point they would concede in their later statements. Their acquisition of data was unsystematic and relied on impression and intuition far more than is typically required for a scholarly article. Often, the authors wrote several pages without citing any relevant literature or their own data sources. By contrast, researchers Patricia Gurin and Edgar Epps, who wrote about Black higher education at the same time (and also did not refrain from criticizing Black colleges), included a clear explanation of their method and rigorous citations (Gurin, 1966; Gurin \& Epps, 1966). Likewise, Earl J. McGrath's comprehensive study of Black colleges clearly indicated the source of the data (interviews conducted by the researcher) and explained the questionnaire used to obtain the data (McGrath, 1965). According to Benjamin E. Mays, then president of Morehouse College,

just before [the Jencks and Riesman] study was done in 1965 there was a study done of black colleges whose methodology I think was unquestionable. This is the McGrath study of the black colleges by the title of Negro Colleges in Transition, and if McGrath had arrived at conclusions such as [Jencks and Riesman], he at least had done the visiting, had at least constructed an instrument, an exhaustive questionnaire, talked with a lot of people, and did his homework. But he reached no such conclusions as Jencks and Riesman did. (Mays, 1987, p. 112)

With regard to their portrayal of Black colleges, Jencks and Riesman pointed out on several occasions that not all Black colleges are alike; however, their discussion of the issues pertaining to these institutions neglected to keep this notion in mind. With the exception of the "Negro Ivy League" (Fisk, Spelman, Morehouse, Hampton, Tuskegee, and Dillard), Jencks and Riesman labeled the 50 large public Black colleges and the 60 small private Black colleges "academic disaster areas."6 Grand statements like the aforementioned one are typical of the Harvard Educational Review article's language. 
Coming to their research with an incomplete set of facts and a flawed understanding of the historical and contemporary issues facing Black colleges, the Harvard sociologists often made distorted claims about their subject. ${ }^{7}$ For example, in reference to the Civil Rights Movement, Jencks and Riesman stated, "the Negro college campuses have not, with few famous exceptions, been the center of protest in the South, nor have they provided the shock troops for organizations like the Student Nonviolent Coordinating Committee" (Jencks \& Riesman, 1967a, p. 27). In fact, there were more than a few exceptions, including both North Carolina A\&T and Shaw University (mentioned earlier) as well as Tougaloo College. Moreover, prior to the 1960s, Fisk University's renowned Race Relations Institutes provided an intellectual foundation for the Civil Rights Movement—giving a forum to Martin Luther King, Jr., as well as a variety of international guests who spoke about the growing agitation against colonialism.

In many ways, Jencks and Riesman followed a long line of research (including the Moynihan Report) by generally liberal thinkers who did a disservice to Blacks by attributing all of their current problems to the legacy of slavery - thereby denying them agency and overlooking Black accomplishments since slavery (Moynihan, 1965; Stuckey, 1987). ${ }^{8}$ The problem with this understanding is it has a tendency to see Uncle Tom-like behavior (and other forms of self-hatred) in current Black leadership: hence Jencks and Riesman's mischaracterization of Black colleges as not being incubators of civil rights protest. This understanding also tends to ignore the contemporary context-that is, the effect of recent history, and the role that Blacks played in these events. This is not to say that Blacks did not suffer debilitating effects, both from slavery and segregation. Nor is it to say that Blacks have only themselves to blame for current troubles. But to characterize these problems as an unchanging holdover from a time long passed is to deal African Americans a double blow: first, to depict them as putty in the hands of an oppressor, then to deny them the ability to grow and adapt to freedom. For a fuller understanding of Black agency, researchers must look at the situation from multiple perspectives.

In spite of the generally negative portrayal, Jencks and Riesman looked to a future for Black colleges and their graduates in the organization of their article. Although they thought that Black students would be better off at predominantly White institutions, they saw Black colleges attracting the children of their alumni for years to come. However, if the intended effect was to identify the problems faced by Black colleges and make predictions for the future, this goal was undermined by the author's blanket criticism of these institutions, lack of understanding of 
their contemporary situations, and most importantly, failure to comprehend the colleges' role in incubating change within Black society at the time. Not surprisingly, the Black community, and in particular the presidents of the United Negro College Fund's member colleges, was outraged. ${ }^{9}$

\section{Responding in the Media}

Because of the national reputation of both Christopher Jencks and David Riesman, the content of "The American Negro College" was picked up by the popular press. ${ }^{10}$ In the words of Morehouse president Benjamin E. Mays, "Riesman? Harvard? The Harvard Educational Review? [They carry] automatic endorsement for lots of people" (Mays, 1987). Articles in Time and The New York Times discussed the most scathing comments made by the authors, leaving out most of the contextual information. Time, for example, reported,

Despite the steady increase of Negro students at the nation's major universities, the U.S. still has more than 120 colleges that have a predominantly Negro student population. How good are they? In the current issues of the Harvard Educational Review, sociologist David Riesman and Christopher Jencks, a contributing editor of The New Republic, deliver a soberly scathing judgment. The Negro colleges, they argue, constitute an "academic disaster area." (“The American Negro College," 1967, p. 64)

The Time statement that the United States "still has more than 120" Black colleges suggests the widely held view that these institutions were a leftover-no longer needed in a post-Brown era. Thus, the article was imbued with negative assumptions about Black higher education (Gasman, 2003a). Although the Time article was careful to note that the "facts" about Black colleges were the opinions of Jencks and Riesman, its tone implied that these "facts" were authoritative. Their magazine not being an academic publication, the editors of Time neither critiqued the data collection methods nor the unsubstantiated assumptions contained in the Jencks and Riesman article. Time merely reported the findings that were most inflammatory. The magazine also quoted Jencks and Riesman's descriptions of Black college leaders as "domineering but frightened president[s]" who "tyrannized the faculty." Moreover, according to the article, the two Black medical schools (Meharry and Howard) reportedly "rank among the worst in the nation, and would probably have been closed long ago had they not been a main source of doctors willing to tend Negro patients." Summarizing the situation, Time noted that according to Jencks and Riesman, Black colleges were "an ill-financed, ill-staffed, caricature of white higher education" (Jencks \& Riesman, 
1967a, p. 64). This coverage essentially popularized Jencks and Riesman's phrase "academic disaster areas" as an overarching description of all Black colleges and thus intensified the anger and sense of betrayal felt by the Black academic community. Jencks and Riesman themselves thought the Time magazine portrayal of their work was an "extremely one-sided summary, which quoted [their] gloomiest judgments" (Jencks \& Riesman, 1968, p. 475). In fact, the Harvard sociologists tried to provide a rebuttal to the Time article, but the news magazine refused to publish their "letter of protest." Their rebuttal would not have disavowed the material quoted, but would have reported a more well rounded version of their research (Jencks \& Riesman, 1968, p. 457).

The extent of the impact of the Time magazine coverage and the diversity of responses to the piece were evident in the letters to the editor contained in the April 14, 1967 issue of Time. Cognizant of American race relations and with an interest in selling magazines, the news outlet allotted several pages to both angry and supportive readers. ${ }^{11} \mathrm{C}$. Shelby Rooks of The Fund for Theological Education in Princeton, New Jersey, took issue with Jencks and Riesman's characterization of Black colleges, noting,

Despite unconstructive criticisms and lack of adequate resources, they [Black colleges] do much more than give their students "an idea of what middle-class life is like." The truth is that the vast majority of Negroes who today achieve success in American life were educated in this "academic disaster area." (Rooks, 1967, p. 19)

Likewise, Sarah Bedichek Pipkin, an Associate Professor of Zoology at Howard University, wrote,

I heard Mr. Jencks address the liberal arts faculty at Howard University on March 22, telling us we were second-rate and would always be so. He admitted that his investigation of Negro colleges was "journalistic" and "impressionistic," not based on statistics or formal research. . . . As a scientist, I feel that Riesman and Jencks would have performed a service to education had they done more serious researching and had fewer impressions. Their [research] will only provide fuel for segregationists of both races. (Pipkin, 1967, p. 21).

On the other hand, Lloyd T. Jones, a graduate of a Black college living in Washington, DC, noted in his letter,

Riesman and Jencks have a valid argument. As a victim of a Negro secondary and college education, I will say this: the Negro-educated Negro, in college especially, is in a wonderland, a system so confused with nonessentials that if we were not so backward to begin with, there would be no hope for survival. When the college is supported by a church, it seems that the thing the college does best is defeat its purpose. The best description of 
education by and for Negroes is found in Elliot Baker's A Fine Madness: "We have come a long way toward ignorance and all uphill" (Jones, 1967, p. 21).

As was typical for a popular magazine like Time, letters to the editor were either strongly in favor or strongly against Jencks and Riesman's opinions - without offering much specific critique or new information. What was remarkable was the volume of correspondence that this issue generated. Other issues covering race-related topics, including Martin Luther King, Jr., the Black power movement, or Black soldiers in Vietnam, had generated far fewer letters. ${ }^{12}$

\section{The Black College Response}

According to Christopher Jencks (in a much later interview), "Anyone writing about race at [this] point in history knew that these were sensitive issues" (C. Jencks, personal communication, September 30, 2003). James Coleman's Equity of Educational Opportunity and Daniel P. Moynihan's The Negro Family: A Case for National Action had just been released to harsh criticism from the Black community, the country was in the midst of heated racial dialogue that sparked riots and protest, and, in response, Black college presidents took on a more activist stance (Coleman, 1966; Moynihan, 1965). With a new sense of Black identity and purpose, these leaders banded together in support of their institutions. However, Jencks was "surprised at the intensity" of the Black response to the article:

I underestimated how rapidly the racial climate was changing in the United States. We had written things that had provoked a lot of upset before-for example, the work we did on Catholic colleges. I didn't foresee the response we got [to the Black college work] and I kind of thought it would be like the response to our Catholic college work. (C. Jencks, personal communication, September 30, 2003)

What was remarkable about the Black college response was that it was coordinated and carefully structured. The Black leaders began their rebuttal with a letter to Time crafted by UNCF president Stephen J. Wright. In the letter, he attacked specific allegations of the Jencks and Riesman article. For example, in response to the claims of cowardly and tyrannical behavior by Black college presidents, Wright suggested that the authors really had not done their homework:

This is an unsupported judgment. While there are, I feel certain, some domineering presidents among Negroes as there are among whites, the great majority are not, in my judgment, either frightened or domineering. And anyone 
who thinks that a president can tyrannize a faculty or a study body in the college simply does not know either the faculties or the students. (Wright, 1967b)

Likewise, in response to the allegation that Black medical schools "would have been closed a long time ago had they not been a main source of doctors willing to treat Negro patients," Wright asserted the quality and viability of these institutions: "Howard and Meharry are not $a$ main source of such doctors, they are the main source. They would not have been closed long ago, for they could have and can now be filled with white students" (Wright, 1967b). Wright ended the letter with a strong endorsement of Black colleges noting that their primary mission was to "identify, recruit, and educate" Black students. Moreover, Wright stated, Black colleges "are indeed ill-financed and they do reflect the ills of ill-financed colleges. Unfortunately, adequate finance is one thing that has never been tried to remedy their ills" (Wright, 1967b). ${ }^{13}$ With this comment, Wright exposed the "original sin" of the founding of Black colleges-most of them were established by Whites and were never meant to put Blacks on a level playing field. Equal funding was never part of their founders' plan (Anderson, 1988). Unfortunately, Time magazine did not publishe Wright's letter.

Determined to get a more nuanced view of Black colleges into the debate taking place throughout both academic and political circles, Stephen J. Wright called together three of the UNCF member college presidents to craft an academic response. Along with Morehouse president Benjamin E. Mays, Hampton Institute president Hugh Gloster, and Dillard University president Albert W. Dent, Wright drafted a rebuttal to Jencks and Riesman's article and sent it to the Harvard Educational Review. According to the Journal's editorial board,

"The American Negro College" . . has been the subject of widespread discussion and some misleading publicity. We are pleased to print the following four responses to the article, each written by a leader in Negro education, together with a reply by the authors. We urge interested readers to refer once again to the original article, as well as to the additional responses to it published in the "To the Editors" section of this issue. ("The American Negro colleges," 1967, p. 451)14

Although certain key themes appeared in all of the Black college presidents' rebuttals, they each attacked the Jencks and Riesman study on varying levels and with varying strategies. Some exposed the unfairness of the comparisons made in the article, some questioned Jencks' and Riesman's methods and qualifications, some accused the authors of racial bias, and one drew attention to the struggles that Black colleges had faced and the value of protecting their future. 
The first response was by Stephen J. Wright and was written on behalf of all Black colleges. Wright began by noting that the Jencks and Riesman article "has had such a shattering effect upon Negro educators and those who support the colleges that it needs to be put in perspective" (Wright, 1967a, p. 451). Not only did he spell out the detrimental effect of the article on the Black community, but he also clarified for the journal's distinguished audience what he termed "four significant facts" about Black colleges that "anyone who knows anything about these institutions, should know":

1. That they are, with very few exceptions, overwhelmingly undergraduate institutions and therefore cannot be seriously compared with universities;

2. That as a group, they have served and continue to serve, with some exceptions, the most culturally deprived college students in the nation, which means that their students, in the main, do not enter with "Ivy League" preparation;

3. That with very minor exceptions, they have been, and still are, the underfinanced colleges of the nation, with all that this implies;

4. That despite these all but insurmountable handicaps, they have managed, somehow, to develop a very substantial number of Negroes who qualify to teach in the public schools across the nation, who qualify for admission to medical colleges and eventually pass state and national medical examinations, and who qualify for admission to graduate schools of the arts and sciences and earn doctoral degrees and even teach, in modest numbers, in the predominantly white universities - not to mention the Negro colleges (Wright, 1967a, pp. 451-452).

These "facts" provided a sense of the playing field at Black colleges for the readers before they began to judge the institutions. Wright pointed out Jencks and Riesman's failure to take into account the historical disadvantages and the uniquely challenging mission of Black colleges.

Wright then moved on to critique the very core of the Jencks and Riesman article - the data collection method. Specifically, he charged,

The article is not a report of a thorough-going scientific investigation. It is rather a reportorial essay, replete with unsupported generalizations, judgments, speculations, impressions, and a good many errors, stated or implied, and written in unscholarly language, i.e., language that makes extensive use of loaded words and phrases which are not adequately defined: "Uncle Tom," "academic disaster areas," [and] "Who the hell do you think you are? [a]ttitude" (Wright, 1967a, p. 452).

Expanding on his criticism, Wright stated,

As a reportorial essay, it reports impressions of what others are alleged to have said, and draws sweeping "conclusions"-not reasoned judgments based on actual findings - from impressions and anecdotes. In a sense, it is not even good reporting because the authors fail to distinguish in importance 
between what they themselves have seen, experienced, or researched, and what they were told (Wright, 1967a, p. 453).

Wright went on to give many examples of the mistakes and generalizations in the article. He also pointed out the most damaging aspect of the piece, that it was written by men of great stature and published in a highly reputable journal, noting that if this were not the case the article would have received little attention (Wright, 1967a). It was Jencks and Riesman's research methods that drew the greatest fire by the larger academic community (those that supported Black colleges) as well.

In concluding his attack on the methodological approaches, lack of fact checking, and overall arrogance of the Jencks and Riesman article, Stephen J. Wright took his criticism a step further and called into question the motives of such research: "It is difficult for me to understand, without serious question of racist motives on the part of the authors, how responsible scholars could put such damaging impressions in print without evidence, which they freely admit they do not have" (Wright, 1967, p. 454).

Like Wright, Benjamin E. Mays was critical of the method used by Jencks and Riesman. However, Mays focused his assessment on their comparison of Black colleges to elite White institutions and the Harvard professors' lack of equal criticism for struggling White colleges. Mays pointedly stated,

When they say, "In part, the problem is that no Negro college's B.A. carries the same weight as one from Harvard, Oberlin, or Berkeley" (p. 47), they talk like uninformed men. Do they not know that possibly 90 per cent of all white colleges are not in a league with Harvard, Oberlin, and Berkeley? Harvard College is part of a university which, I hear, has an endowment of one billion dollars, and Oberlin is one of the best endowed colleges in the nation. The College of the University of California at Berkeley is part of one of the great universities. This kind of comparison is ridiculous and unfair. (Mays, 1967, p. 456)

He then elaborated, noting the unequal standard to which Black colleges were being held:

Two years ago, there were 401 predominantly white colleges in the country too feeble in academic performance to be rated by any one of the six regional accrediting agencies, which places them below the weakest of the accredited Negro colleges. It is strange indeed that no article has been written describing these colleges as areas of "academic disaster." (Mays, 1967, p. 456)

Mays' comments were similar to those made a few years earlier by Earl J. McGrath. In an eerily accurate prediction of the unfair comparisons made by Jencks and Riesman, McGrath said about his own review of Black colleges (even mentioning David Riesman's earlier writing): 
If this report does nothing else, it should establish the fact that, except at the topmost level of excellence represented by a few celebrated institutions, the Negro institutions run the entire gamut of quality within American Higher Education. Some educators as well as laymen unfamiliar with the Negro colleges seem not to realize this fact. Occasionally they appear to believe that the nation's predominantly Negro colleges make up a small isolated band of institutions at the end of the American academic procession-the procession of colleges and universities that David Riesman has depicted so graphically as a snake-like line, led by experimental avant-garde institutions, followed by a multitude of colleges attempting to keep up with the first, and tapering to a long, trailing line of weaker institutions that form the tail. (McGrath, 1965 , p. 5)

Hampton Institute president Hugh Gloster also wrote a response to the article on behalf of all Black colleges. Although he pointed to some of the same issues as Wright and Mays addressed, Gloster took a special interest in exposing the racist assumptions and sense of racial superiority embedded in the article. Specifically, Gloster pointed to Jencks and Riesman's glaring exclusion of any exemplary examples of Black college graduates. In an incensed tone, Gloster wrote,

It has been said that the main contribution of Negro Americans to white Americans is a lower socio-economic status that allows the latter group to have smug feelings of racial superiority. Although Jencks and Riesman are knowledgeable enough to understand that Negro disadvantage is a product of white prejudice, they also reveal symptoms of racial complacency. For example, although they do not tell a single success story concerning a Negro student or professional person in a sixty-page article, they do amusedly describe an unidentified Negro dean whose "head often itched when he talked to white men, because as a child he had habitually assumed the 'darky' pose of scratching his head and saying 'Yassir' to white men" (p.7). (Gloster, 1967, p. 458)

The last response to the article from a Black college president was that of Dillard University's Albert W. Dent. Dent took a very different approach from those of Wright, Mays, and Gloster, finding an overall positive picture in an article that he claimed the authors filled with "impressions" and "moribund stereotypes" (Dent, 1967, p. 461). According to Dent, when looked at from a slightly different and clearer point of view, Black colleges had had a heroic past-persevering in spite of disadvantages, and potentially flourishing in the face of current criticisms being heaped upon them:

The real good that can possibly come from this article will derive from the fact that it does call dramatic attention to a group of colleges that have too long struggled against almost impossible odds to provide an adequate education for several generations of Negroes who were denied education in other colleges. Thus it is hoped that instead of arousing damaging public 
condemnation of these institutions because they do not measure up to Harvard (which seems to be the unstated norm according to which the authors judge Negro colleges), the article will stir fair-minded individuals, philanthropic agencies, and government on all levels to see an opportunity to make a needed, lasting contribution to American higher education. If the condemnation by the authors serves to remind Americans that these colleges are, and always have been, in the forefront of discovering and developing otherwise wasted potential talents among disadvantaged youth, it may after all serve a worthwhile end. (Dent, 1967, p. 462)

Dent examined specific points made by Jencks and Riesman and provided readers with another way of viewing them. In many ways, he urges readers to acknowledge the ills of slavery and Jim Crow, but to avoid letting the reporting of these ills mask the agency and efforts of Black college leaders and Black colleges on behalf of their students. For example, he admitted that many Black colleges enroll students who might not otherwise be able to attend White institutions. However, he informed the reader of the steps that Black colleges were taking to compensate for the skills garnered at "inadequate high schools" (Dent, 1967). ${ }^{15}$ Dent identified the prefreshman programs at Dillard, Morehouse, and Spelman that received national attention in 1959. These programs were designed to "bridge some serious academic gaps between an inadequate high school education and the freshman college program" (Dent, 1967, p. 462). He also pointed to the federal government's Upward Bound initiative. According to Dent, because of improvements in high school environments and programs like those mentioned above, "the future of Negro college graduates seems brighter than ever before" (Dent, 1967, p. 463).

Closing the UNCF and Black college response to Jencks and Riesman were Dent's stinging but forward thinking comments:

I would expect a more factual and positive approach to the problems of the Negro college than that of scholars like Jencks and Riesman. But it may be that what they have written will underscore what Negro college administrators have insisted upon over the years - namely, that with the proper understanding and support of the American people, these colleges can make a distinct contribution toward establishing. (Dent, 1967, p. 464)

\section{Support from the Wider Academic Community}

Concurrent with but independent of the UNCF's organized response in Harvard Educational Review were other letters to the editor that attacked Jencks and Riesman on similar grounds. For example, Elias Blake, Jr., ${ }^{16}$, who was an early reader of the manuscript, began his comments by rejecting the indebtedness Jencks and Riesman expressed to him in the acknowledgment section of their article: 
Since Messrs. Jencks and Riesman list my name as one of those to whom they are indebted, I would like, if I could to diminish that debt by making here the major criticism of the article I made when it was in manuscript form and which in essence were ignored or brushed aside as the authors pursued their conclusions. The criticisms were summarized as follows: The chapter as now written is a dangerous document and a misleading one. Certainly, it is not based on enough reading in the field. (Blake, 1967, p. 472)

Blake then continued in his critique, detailing what about the article's method made it dangerous. With great fervor, Blake avowed:

The article is dangerous . . . because it makes sharply attacking statements about Negro colleges and in some instances Negroes, e.g., "Negro colleges serve as a living reminder of how bad most white colleges ... had been" or anecdotal evidence suggests "[dishonesty] is more common at the poorer ones [Negro colleges]" or "professors . . . blackmail students into providing sexual favors" or that as to being benighted and corrupted "Southern Negro colleges are in a class by themselves." These statements sound more like charges which a prosecuting attorney makes about a defendant he is out to convict than a dispassionate analysis of relevant issues based on sound evidence (Blake, 1967, pp. 472-473).

Like Gloster, Blake attacked the racist undertones of the article:

When the "friends" of Negroes attack their institutions for the afflictions they endure in a still racist society and do not mount equally venomous attacks on racism itself but rather blandly describe its results, those "friends" are like the father (paternalistic symbol intended) who beats his son to death for only surviving but not winning a fist fight with two boys twice as big. (Blake, 1967, p. 473)

Blake's letter supports the notion that Jencks and Riesman merely saw Blacks as victims - imitating Whites because they suffer from internalized racism - rather than leaders acting on behalf of their people.

However, not all of the letters to the editor saw Jencks and Riesman's article and their actions as racist. Julian C. Stanley, of the Center for Advanced Study in the Behavioral Sciences at Stanford University, saw the article as balanced and lauded the authors for not including more statistical comparisons - noting that it was much more readable without them. Stanley also took the opportunity to include some statistical comparisons, specifically in the area of standardized tests. He concluded that based on comparisons of Black and White SAT scores, most Black students would not, regardless of racism in college admissions systems, be eligible to attend predominantly White institutions. Although Stanley made this claim, and noted that the abolishment of Black colleges would mean many Black students would have nowhere to go, he supported Jencks and Riesman's call to close many of the small, struggling Black colleges (Stanley, 1967, 475-476). 
Responses to the Jencks and Riesman article were also appearing in other academic publications. For instance, John Sekora, a Woodrow Wilson Fellow at Princeton University, was enraged by Jencks and Riesman's article and wrote a peer-reviewed response in 1968. Augmenting the voices and ideas of the Black leaders, Sekora took specific issue with the tone, method, and "blatant" dismissal of already existing Black scholarship. Sekora referred to Jencks and Riesman's tone as "brittle, reductive, and dehumanizing," and described their method as using "random, selective impressions to further [their] arguments where no statistics exist" (Sekora, 1968, p. 7). He pointed to the abundance of scholars who had written specifically on issues related to Black colleges that the Harvard sociologists chose not to draw upon, including Horace Mann Bond, Carter G. Woodson, Louis R. Harlan, Charles W. Dabney, and Saunders Redding (Sekora, 1968). A lifelong defender of Black accomplishments and author of The Art of Slave Narrative, Sekora was most critical of Jencks and Riesman's portrayal of Black college presidents. According to the Princeton scholar, the authors failed to acknowledge the forward-thinking actions of Black college leaders and any evidence to the contrary of the "Uncle Tom" stereotype they perpetuated. ${ }^{17}$ Specifically, Sekora charged,

they have no room in their purview for the presidents who opened their campuses and even their homes to civil rights meetings. . . . They have no room for those presidents who for years gave half of their meager salaries to the NAACP; or for those presidents and deans who marched alongside their students in the early 1960's. (Sekora, 1968, p. 19)

Most importantly, Sekora upbraided Jencks and Riesman for reporting the "tales of academic horror committed by the [Black] colleges" but ignoring the "frequency of senseless violence against Negro colleges" (Sekora, 1968, pp. 18-19). For example, in 1961, both Jackson State University and Tougaloo College students were confronted with "blockades, tear gas, billy clubs, and attack dogs" while protesting on behalf of their civil rights. The Mississippi police arrested students, worked with members of the local community to disband their organizations, and enforced stiff rules regarding student conduct (Williamson, 2003, p. 25).

Years later, John T. Casteen would offer a very pointed critique of the biases in Jencks and Riesman's rhetoric and style. This came in his 1998 review of their book The Academic Revolution, in which the "Negro colleges" article appeared as a chapter. Casteen noted,

sections of the book often turn on broad arguments that are, by their nature, beyond proof. To argue, as Jencks and Riesman often do, that something is "for the most part" or "seldom" so is, in a sense, to avoid the burden of proof, since contrary cases belong to the unimportant minor part of the 
generalization. To go beyond this kind of generalization to argument by blanket categories, especially categories that are blatantly exaggerated, and then slip into sarcasm that makes objectors, quibblers by definition (that is, those who have come to believe their own talk) is to sidestep proving or demonstrating the core argument. (Thelin, Casteen, \& Bailey, 1998, p. 3)

Like Sekora, Casteen took aim at the tone of Jencks and Riesman's article, saying that the style of writing itself tended to undermine rational debate about the chapter's claims.

\section{Jencks and Riesman's Response to the Black College Leaders}

Christopher Jencks and David Riesman took advantage of two opportunities to explain themselves and their provocative article. The first took place in the summer 1967 issue of the Harvard Educational Review and sat side-by-side with the responses of the Black college presidents. As a whole, Jencks and Riesman's responses addressed details but not the substance of the accusations against them. They diminished the importance of their own work, but later claimed a kind of moral duty to point out glaring problems that others declined to tackle. They admitted to faults, but in such a way as to deride their accusers as being, in the words that Casteen would later use, "quibblers." They dodged the blame for generalizations and omissions by attributing them to the larger, racist society and to the Black colleges themselves.

Blaming others for exaggerating the significance of their research, Jencks and Riesman began their Harvard Educational Review response by explaining that their article was "not the result of a major research project aimed specifically at Negro colleges." The Harvard sociologists' response in this case leads the reader to wonder why the authors published their work, which was "not a major research project," in a major education journal. Although the professors never fully answered the question, they did inform the reader that this "chapter" was part of a larger aforementioned project, The Academic Revolution, "which attempts to describe many different sorts of colleges and universities as products of history and current social forces" (Jencks \& Riesman, 1967b, p. 465). But The Academic Revolution would go on to win the American Council on Education's Borden Prize for Best Book on Education. In a remark difficult to read without inferring a tone of condescension, the authors pointed out that the inclusion of a chapter on Black colleges was a tribute to the increasing importance of these institutions, and they noted that in an earlier work on the American academic enterprise, they only allotted two sentences to these institutions (Jencks \& Riesman, 1967b). Although Jencks and Riesman gave themselves some 
credit for bringing Black colleges to the fore, in fact, it was the activist Black scholars of the 1960s and 1970s (those who pushed for Black studies programs) who were largely responsible for the increased interest in these institutions (Gurin \& Epps, 1975).

Justifying their research, Jencks and Riesman strategically argued that American higher education overall, not they as the authors, was caught up in comparisons to Harvard, Oberlin, Berkeley, Rice, and so on-that colleges used these institutions as benchmarks. Jencks and Riesman illustrated this phenomenon by pointing to the accusation that they were calling for the "closing down" of Black colleges. They were not. Instead, they were suggesting that these institutions be strengthened in "non-imitative ways" (Jencks \& Riesman, 1967b, p. 466).

Faced with glaring errors and omissions in their work (identified by the Black college presidents), the sociologists deferred to their Black college critics, explaining themselves when possible. In reference to the accusation that they focused on "Uncle Tom-like" behavior, Jencks and Riesman responded by splitting hairs - admitting wrong in some areas but reiterating the basic truth of their claims. For example, addressing a critique of their comments made about internalized racism and Black college beauty queens (i.e., that lighter skinned women won), Jencks and Riesman said, "On the color of Negro college beauty queens, we defer to Dr. Wright's judgment. We note, however, that when a girl with a 'natural' hairdo was crowned this year at Howard University, the event was described there as unprecedented" (Jencks \& Riesman, 1967b, p. 467). Jencks and Riesman were correct in part; conservatism was prevalent on some Black college campuses. Black intellectuals such as E. Franklin Frazier pointed this out years earlier in his classic work Black Bourgeoisie (1957). ${ }^{18}$ However, Jencks and Riesman failed to talk about these incidents as individual cases and did not give credit to those Black college presidents and administrators, such as Adam D. Beittel at Tougaloo College, who whole-heartedly backed the Civil Rights and Black power movements (Carson, 1981; Morris, 1984; Williamson, 2003).

In addressing their critique of the Black medical colleges, Jencks and Riesman also brought new material to the table. They began by pointing to the numerical evidence that showed Black medical colleges to be inferior and then introduced data to show that Black medical students scored much lower than their White counterparts did. Jencks and Riesman concluded from this data that, "given the raw material they get, these two medical schools [Meharry and Howard] may do a better job than most white schools" in educating students. However, according to the Harvard researchers, "data which would test this hypothesis [was] not . . . available to us" (Jencks \& Riesman, 1967b, p. 467). 
Jencks and Riesman concluded their reply by suggesting that Black colleges investigate the "value added" impact that they might have on their students. How? They suggested that Black colleges conduct comparison studies between SAT scores for incoming students and GRE scores for graduating seniors. Of course, Jencks and Riesman failed to wrestle with the fact that the very nature of standardized tests is problematic, as is the comparison of performance on two very different exams. Regardless, they suggested that if Black colleges conducted this type of research, the colleges would be less likely to suffer the criticism of outsiders. In their words,

If Negro colleges were to investigate this question systematically, they could not only perhaps find evidence to silence critics such as ourselves but show white colleges the way toward candor. Consumer research of this kind, while depressingly rare, is nonetheless the only way to rescue students, faculty, administrators, and outsiders from continuous vacillation between total despair and unjustifiable euphoria. We are not, however, optimistic about what it will show. (Jencks \& Riesman, 1967, p. 468)

This call for additional research leads one to ask: If Jencks and Riesman professed to measure the quality of Black colleges, why didn't they do the study that they proposed here instead of their "impressionistic" and "personal" one? The pessimism with which they greeted any such future study provides the answer: They did not see the need for more careful research because they believed that their impressions were enough.

But, in fact, more systematic research than Jencks and Riesman's work was already available. The work of the sociologists' contemporaries was more balanced in its portrayal of Black colleges. As mentioned earlier, Earl J. McGrath studied and collected data on faculty and administration, curriculum, physical plants, support services, students, and financial viability. His method included survey research and qualitative interviews via campus visits (Williams, 1988). Partly because of his rigorous methods and willingness to consult with members of the Black college community, McGrath produced an evenhanded study. Nevertheless, McGrath's report did point to areas of weakness among Black colleges - $\mathrm{a}$ fact that the researcher thought would aid in their improvement. In summarizing his report, McGrath noted:

To be sure, this type of general approach which often results in the portrayal of general features rather than catalogues of individual institutional characteristics has some disadvantages. Since in many features of institutional life the averages fall below those for the colleges and universities of the nation at large, some may feel that the figures do an injustice to the better institutions, or even to all of them. This position rests on an assumption of questionable 
validity; namely, that if the weaknesses of some are exposed all will be commensurately depreciated and some or all of the Negro colleges will unfairly lose prospective additional financial and moral support. (McGrath, 1965, p. vi)

McGrath believed that his report would have the opposite result, noting "that the revelation of the weaknesses of some and the needs of all will generally swell the flow of new support" (McGrath, 1965, p. vi). In pointing to these institutions' shortcomings, he was especially careful not to compare them to White institutions in different categories (e.g., comparing Dillard to Harvard). He noted in the Foreword:

As the report repeatedly states, on any measure of faculty competence, library facilities, salaries, physical equipment, and a host of other characteristics, the predominantly Negro institutions run the entire gamut from the highest to the lowest. When compared with the predominantly white colleges they can be matched institution by institution. (McGrath, 1965, vii)

With the publication of The Academic Revolution, Jencks and Riesman had a second opportunity to comment on the reaction to and criticism of their original article, and to make changes to the article/chapter itself (Jencks \& Riesman, 1968).19 This time they had more column space and more time to think about their response. The authors of The Academic Revolution began their commentary with a rather apologetic defense of their method-one that seemed to respond to widespread criticism by both Blacks and Whites and that continued to be identified with the book well into the late 1980s (Sekora, 1968; Thelin, Casteen, \& Bailey, 1998). In their commentary, Jencks and Riesman explained their method as "personal rather than impersonal":

We visited a number of Negro colleges for relatively short periods, talked to or corresponded with many knowledgeable insiders and outsiders, read the better-known books and articles on the subject as well as some obscure ones, listened to critics who said we were wrong on particular points, and made numerous corrections in response to their objections. Other writers who visited the same colleges, talked to the same informants, and read the same materials might well have come to different conclusions. Yet this does not strike us as a serious objection (Jencks \& Riesman, 1968, p. 476).

What does strike the reader is the sense that Jencks and Riesman continued to pass off "causal reporting" as academic research. In a recent interview, Jencks commented, "Someone once told me that sociology is slow journalism. I would describe what we did in those terms. It was not the kind of social science people do these days-including me. My current work is much more based on quantitative evidence." Looking back, Jencks explained, "I would have been more cautious about some of the 
things we said. I would have made more attempts to document what we saw. However, I am not sure if that would have brought us to different conclusions" (C. Jencks, personal communication, September 30, 2003). Yet the author's explanation does little to deflect UNCF president Stephen Wright's original assertion that this article is really "fast and loose journalism": by failing to distinguish between honest impressions and hearsay, it does not rise even to the standards of good reporting, let alone academic research.

Jencks and Riesman also responded to the criticism that their outsider status made them poor candidates to undertake this study. Dismissing the idea of leaving the research to Black intellectuals because it is "not our style," the Harvard professors claimed that it was "much harder for a Negro to say these things than for a white to do so." According to Jencks and Riesman, "Whoever says them will, after all, antagonize most of the Negro leadership." On this note, they began to claim a kind of noblesse oblige-the status of two privileged people whose position obligated them to take on sacred cows that others were afraid to touch. As an example of the hostility potentially felt by Blacks critiquing Black education, Jencks and Riesman cited E. Franklin Frazier-noting that "few wish to endure the persecution he got after writing Black Bourgeoisie" (Jencks \& Riesman, 1968, p. 477). ${ }^{20}$ Unlike their Black colleagues, "Whites . . . can afford to make sure enemies" (Jencks \& Riesman, 1967, p. 477). What Jencks and Riesman did not acknowledge was that others had taken up the mantle of critically examining Black colleges without drawing nearly as much fire. Earl J. McGrath's work, as I have already mentioned, was critical of Black colleges, yet used research-based findings to make recommendations for their future (Mays, 1966; McGrath, 1965).

Justifying their research in the face of their critics, Jencks and Riesman stated that

This is a moment when Whites can do no right [in the study of Black colleges]: the critics are viewed as traitors and the supporters as gullible fools to be used as best one can. Under such circumstances one might as well forget about winning friends and do what one thinks is right. (Jencks \& Riesman, 1968, p. 477)

These comments certainly summarized the incendiary atmosphere of the 1960s, in which race and politics divided college campuses and public discourse at large. Although the two viewed their research as supportive of Black colleges, many in the Black community did see it as a "betrayal of the cause." The well-placed article and its resulting national media coverage made it harder for Black colleges to raise money and recruit faculty. In the words of Benjamin E. Mays, 
I think whenever the image of an institution is damaged an impact is made. It isn't always easy — or it's probably never easy — to assess exactly what that impact is, but if it leads to a conclusion that these institutions are not worthy of support or even existence, in the minds of important people it can do damage over a period of time (Mays, 1987, p. 112).

Jencks and Riesman doubted that their article could have this kind of impact, stating, "It is an insignia of the marginality of these colleges that they should assume one article of this kind, written by men who control no resources and have only the most marginal official influence, could seriously affect their future" (Jencks \& Riesman, 1968, p. 477). In making this statement, the authors seemed to have ignored obvious facts of their situation - that they were Harvard professors publishing in a highly respected journal. Thus, the justifications presented in The Academic Revolution went no further toward redeeming the researchers from accusations of racial superiority and condescension than those published in the "Response" issue of the Harvard Educational Review.

In closing their chapter on Black colleges, Jencks and Riesman stood behind their method and conclusions, but appeared to take ownership for the "abrasive" tone that they used throughout the chapter/article. They admitted that some of the critique regarding tone was justified-noting that, "Oppression corrupts the oppressors as well as the oppressed. Ultimate responsibility for this corruption rests with those who have power, and in the last analysis this means prominent whites." However, the authors were not able to reassign the blame for long. They ended their chapter by making clear that "Today most of the men who exercise dayto-day power in Negro colleges are Negroes. They may not be morally responsible for their failures, but they are often administratively responsible" (Jencks \& Riesman, 1968, p. 477). With this statement, Jencks and Riesman acknowledge the agency of Black leaders only concerning their failures.

\section{Spinning Black Colleges in the Media}

In 1968, one year after the publication of their article, Jencks and Riesman's research again drew national attention in a piece published in the popular media, and Black colleges were faced with more negative press. An article in Time entitled "The New Black Presidents," although much more positive in its overall tone, began by reminding its readers of the Harvard sociologists' work. Referring to the Black college president, the article said, "However bombastic in the pulpit, they made a point of being obliging to White authority. They demanded little, and they got little. The result was what Sociologists David Riesman and Christopher 
Jencks have denounced as 'ill-financed, ill-staffed, caricature of white higher education'” ("The New Black Presidents," 1968). In all fairness, and perhaps a sign of the race-related change that was taking place in the United States, the Time article went on to compliment the new leadership at Black colleges. ${ }^{21}$ For example, the article referred to Vivian W. Henderson, then president of Clark College in Atlanta, as "an expert in the game of grantsmanship ... [and] a man of fearsome energy" and to Norman C. Francis, then president of Xavier University of Louisiana, as "reflecting both pride and competence" ("The New Black Presidents," 1968). The problem with Time's portrayal and thus the lasting impact of the Jencks and Riesman article is the misguided view of the Black college presidents prior to 1968 . Yes, there were some presidents who were ineffective; however, there were also individuals such as Charles S. Johnson (Fisk, 1946-1956), Benjamin E. Mays (Morehouse, 1940-1967), and Horace Mann Bond (Lincoln University, 1945-1957) who stood as stellar leaders in the Black community and who were instrumental in training the generation that paved the way for the Civil Rights Movement (Gilpin \& Gasman, 2003; Mays, 2003; Urban, 1992).

Unlike Time, the Chronicle of Higher Education's review of The Academic Revolution was not as kind to Black colleges-it printed direct excerpts from the book. The Chronicle repeated some of the authors' most scathing, pessimistic comments—comments that even Jencks and Riesman tried to distance themselves from in later rebuttals. The Chronicle reiterated the stinging phrase, "By almost any standard these 110 colleges are academic disaster areas." Moreover, although Jencks and Riesman denied vehemently that they called for the closing of many Black colleges, the excerpt in the Chronicle seemed to say just the opposite. In the words of the Harvard sociologists:

Whatever the pros and cons of the matter, very few private Negro colleges will close down, any more than their white counterparts will. They may be academically inadequate, but neither their trustees nor the general public see that as a sufficient argument for killing a live institution. ... So long as these colleges give an otherwise unattainable sense of importance to their trustees, administrators, faculty, and alumni, most will endure.("Whither Higher Education," 1968, p. 8)

Perhaps the only saving grace for Black colleges in the Chronicle article is Jencks and Riesman's equally bleak outlook for higher education overall.

In 1968, another White scholar from Harvard discussed the future of Black colleges with the mainstream media. John U. Monro was the former dean of Harvard College "who made headlines when he left a high post at Harvard to take a job at a Negro school in Birmingham [Miles 
College]" ("Negro Colleges," 1968, p. 74). In an interview with U.S. News \& World Report, Monro, drawing upon a concept introduced by Jencks and Riesman, passionately stated, "The black colleges are moving away from the old ideas that they should be imitative of white colleges. ... These colleges are trying to become distinctively Negro colleges" ("Negro Colleges," 1968, p. 74). When the U. S. News reporter asked "In what way?", Monro responded,

One of the problems has been that the Negro-college curriculum hasn't been attentive enough to the needs of black people. I'm just as sure as I can be that there is a black community with special problems, a special outlook, special needs of organizing to develop its institutional strength. But the Negro colleges, until lately, have seen themselves as mainly preparing people to be teachers or preachers, or to get good jobs in a middle-class white situation a thousand miles away. ... They have offered traditional, adequate, liberal arts curricula—but that will not do anymore. ("Negro Colleges," 1968, p. 74)

More importantly and to the advantage of Black colleges, Monro described them as "centers of black power"- - not in the sense of militant groups such as the Black Panther movement, but meaning "black awareness, black identity, and black pride." In a somewhat radical stance given the situation in the United States at the time, Monro explained for the "average" reader of the news magazine what White power and White privilege were-noting "It doesn't take you very long, living in the Black community, to understand about 'white power." Monro's portrayal, though critical of the past situation at Black colleges, offered one of the most optimistic predictions for the institutions' future. Given Monro's stature as a former dean at Harvard, the UNCF was able to influence potential donors by referring to Monro's ideas. However, even Monro's ideas did not have the lasting impact of Jencks and Riesman's. 22

\section{A More Organized and Informed Response: Charles V. Willie's Harvard Conference}

In the past, information about the adjustment and adaptation of blacks tended to be written by whites affiliated with prestigious institutions. Because of the settings out of which the pronouncements came, these studies were published and acquired the status of standard references on the black experience. (Willie \& Edmonds, 1978, p. ix)

These are the words of Charles V. Willie, an African American professor of education and urban studies at the Harvard Graduate School of Education. ${ }^{23}$ Willie's counter to the work of Jencks and Riesman exemplifies both a "back door" and public means of challenging the sociologists. In 1976, Willie, Ronald Edmonds, and a number of other Harvard 
colleagues hosted a conference, which in effect was an explicit response to the research of Christopher Jencks and David Riesman (C. Willie, personal communication, September 2, 2003). The "Black College Conference" was Willie's way of "challenging the practice of having the majority speak for the minority" (Willie \& Edmonds, 1978, p. ix). Supported by a grant from the National Institute of Mental Health, the conference took place during two separate gatherings in March and April 1976 at Harvard. In Willie's words, "In view of Harvard's unfortunate record on this score, it was an excellent setting from which to launch a major investigation into black education and the education of blacks under the direction of black scholars" (Willie \& Edmonds, 1978, p. ix). The conference participants were drawn from a diverse pool-they were "black and white, male and female, born in the North and the South, young and old, with both extensive and limited experience as faculty and administrators of black schools" (Willie \& Edmonds, 1978, p. ix). Participants included Black college presidents Benjamin E. Mays (Morehouse), Samual DuBois Cook (Dillard), Herman Branson (Lincoln), and Prezell Robinson (St. Augustine), and scholars Daniel C. Thompson (Dillard), Shirley McBay (Spelman) and John Monro (Miles), among others (C. Willie, personal communication, September 3, 2003). Unlike the story told by Jencks and Riesman, the one conveyed by the conference participants included varying perspectives. According to Willie, the Black college conference enabled those researchers "connected to black institutions to set the record straight, exposed the Harvard community to black college presidents and faculty . . , caught the attention of the national press, and presented an opportunity for sociologist David Riesman" to restate his earlier condemnation of Black colleges (Willie \& Edmonds, 1978, p. x). In a recent interview, Willie noted,

I knew about Jencks and Riesman. I knew how angry the Black community was about the article, and so that's why I decided to have the conference. I made sure that we got good press for the event. I had the Washington Post, The Philadelphia Evening Bulletin, Time magazine, etc. at the conference. I used my best sociological skills to get the media to show up. I called Ms. [Katherine] Graham at the Washington Post, as if she handled the day-to-day events at the paper, and asked her to send a reporter. She did. The conference had a tremendous impact upon the Harvard University and Riesman retracted his characterization of Black colleges. (C. Willie, personal communication, September 2, 2003)

Willie's response to the work of Jencks and Riesman's treatment of Black colleges was pointed. Specifically he said,

To call them academic disaster areas was terrible. It was insulting, short-sighted, and arrogant because they [Jencks and Riesman] had no 
understanding of what the Black colleges were doing, were trying to do, and they inappropriately used White colleges as the model for all. This is not unique to these two scholars. This article was written during the same time that Moynihan put out his report on Negro families. Much of the knowledge of Jencks and Riesman about black colleges was derived from the novel The Invisible Man. They didn't think their approach was harmful because they thought they were trying to improve these institutions. The problem was that they didn't realize that higher education needs a range of different kinds of schools to deal with a range of different kinds of students. I don't think that they were deliberately trying to put down Black colleges. I think they did not realize that they needed better information and better consultation. (C. Willie, personal communication, September 2, 2003)

Willie used the Black college conference as an opportunity to set the record straight. With Harvard administrators, including Derek Bok, and faculty such as David Riesman in the audience, Willie stood before the crowd and apologized on behalf of "his" institution for the way Black colleges had been characterized. ${ }^{24}$ Of this incident, he recalled, "No one was going to disagree with me in public. I knew no one was going to oppose what I said. I didn't want my school to look bad in the press and so I apologized for it" (C. Willie, personal communication, September 2, 2003). As mentioned, Willie also used the conference to place Riesman in a situation in which he needed to own up to his actions. According to Willie

I went over to a reporter from the Philadelphia Evening Bulletin and said, "you know the guy who said Black colleges are inferior, he's right over there." So, the reporter went over to see Riesman, and Riesman said "Both Black colleges and I have changed." And, of course the Evening Bulletin published the statement for national circulation. (C. Willie, personal communication, September 2, 2003)

Charles Willie compiled the talks from the Harvard Black College Conference into an edited volume entitled Black Colleges in America, which did not aim to defend Black higher education but instead attempted to answer a question that should have been asked before (by Jencks and Riesman): How have Black colleges fared with their limited resources? The answers to this question, according to Willie, "are of value to any school struggling with issues of racial desegregation and integration, limited financial resources, and students of varying backgrounds and academic preparation" (Willie \& Edmonds, 1978, p. xi).

\section{Conclusion}

Earl J. McGrath's assessment of David Riesman's earlier work was indeed prophetic. Just as the Carnegie researcher had predicted, 
Christopher Jencks and David Riesman produced a book, The Academic Revolution, that had at its core the idea that institutions of higher education could be ordered in a hierarchy — with those at the bottom trying unsuccessfully to imitate those at the top. Such a premise, when applied to Black colleges, had an even darker overtone: that Black colleges, like so many other aspects of Black life in America, were inert victims of internalized racism (C. Willie, personal communication, September 2, 2003). "Negroes and their Colleges" was one of many chapters of a larger manuscript; according to Jencks and Riesman, it did not hold greater meaning than the other chapters in the book (C. Willie, personal communication, September 2, 2003). However, the message of their chapter/article was indeed full of meaning for the Black college community: They came away from it labeled "academic disaster areas." This phrase and many of the other comments included in the publication have had a lasting impact-they continue to be used in subsequent research, to be seen as "truth" by well-meaning scholars, and to be discussed in Black intellectual circles. Moreover, Jencks and Riesman's comments from 1967 continue to shape the view that both practitioners and scholars hold of Black colleges today. For example, in an October 3, 2003, article on racial censorship, conservative Black scholar Thomas Sowell stated, "Today, if you want to read an honest assessment of the Black colleges, you have to go back to a 1967 article by Christopher Jencks and the late David Riesman in the Harvard Educational Review" (Sowell, 2003a, 2003b). Although the Harvard sociologists' intent may not have been tinged with racism, their lack of collaboration and consultation with Black college presidents, their disregard of earlier research by African Americans, and their failure to anticipate the media's use of their commentary led to a report that was racist in its effect. ${ }^{25}$

Hampton president Hugh Gloster urged Jencks and Riesman to see how their actions reeked of racial superiority. However, it was unlikely that the researchers would change their view of the situation without the Black college community coming together to challenge their work. As educational scholar Kassie Freeman points out in her book African American Culture and Heritage in Higher Education Research and Practice (1998), it is imperative that those doing research on Black issues have a solid background in Black history and culture. With such a background, Jencks and Riesman might have had a better understanding of just how a report like theirs could be misinterpreted. To echo the sentiment of John Monro, with greater knowledge of Black culture, the authors might have understood how "White power" operated in a case like this.

On several occasions, Jencks and Riesman tried to diminish the significance of their Black college study. But they also pointed out that 
"97\% of the public" was uninformed about the evolution and practices of Black colleges (C. Jencks, personal communication, September 30, 2003). In a situation in which the general population possesses little knowledge of a given topic, any information that scholars offer has the potential to be interpreted as truth. This is even more likely when the scholars offering it are from Harvard, whose name for many Americans is synonymous with solid, rigorous research and whose very seal bears the word veritas. Because they claimed to inform the public, Jencks and Riesman had a unique obligation that they failed to understand: It was imperative that their characterization be set in context. Published at a time of pronounced racial division, and discretely from the larger book of which it was to be a part (and which would have shown many White institutions to be feeble as well), the article easily gave readers the implication that Black colleges' problems could be attributed to their racial make-up.

But what of Black college president Albert Dent's interpretation of the Jencks and Riesman article? Was it possible for good to come from the publication? Perhaps what Jencks and Riesman did unintentionally was to provide an impetus for more scholars to conduct research on Black colleges, in an effort to dispute the information in "The American Negro College." The individual who came closest to realizing Dent's prediction was Charles Willie. His conference and subsequent publication, Black Colleges in America, not only offered another voice of authority from Harvard, but added credence to the idea that Black colleges have a unique role as repositories of Black history and culture-and to use Dent's words, in discovering "potential talent among disadvantaged youth" (Dent, 1967, p. 462). Since Jencks and Riesman's research on Black colleges was published, there have been several influential studies on the topic, including the work of Daniel C. Thompson (1973), Charles V. Willie (Willie \& Edmonds, 1978), Frank Bowles and Frank A. DeCosta (1971), and more recently, that of Walter Allen (1991) and Henry Drewry and Humphrey Doermann (2001). The difference in this later work was that it was a product of collaborative research between scholars and Black college practitioners. Moreover, this subsequent research possessed an understanding of the historical and cultural context in which Black colleges operated.

Within the culture of vigorous debate and verbal sparring that exists within the academic community, a phrase like "academic disaster areas" might be taken with a grain of salt. However, in the context of the media, especially during a volatile time for Blacks, such a phrase had an incendiary effect. Although researchers should not disguise unpopular findings, they must be cognizant of the negative outcomes possible when 
their work is reviewed in the media. Any bad news about Black colleges continues to have a devastating effect on the institutions as a whole. Recently, several Black colleges have found themselves in dire financial straits-Morris Brown College (Georgia), Bennett College (South Carolina), and Texas Southern University (Houston). Reporters covering these stories have, in the manner of Jencks and Riesman, painted their shortcomings with a broad brush, and sometimes generalized them to include all Black colleges (Basinger, 2003; June, 2002; Poe, 2002). The exaggerated claims of these news articles have gained national attention, jeopardizing the fundraising programs and, in some cases, the existence of the institutions in question (June 2002; Poe, 2002; Simmons, 2002). The historical efforts of the Black college leaders and of Black intellectuals to deflect Jencks and Riesman's criticisms may point the way for current efforts to avert crisis. Charles Willie's actions, on the other hand, were a good example of how scholars can use the media in a way that benefits Black colleges. While the attempts of the Black college presidents to discredit Jencks and Riesman were important, they were ignored by the media. Willie was a clever handler of the media and had the benefit of 10 years of hindsight. Just as Jencks and Riesman had created a "spectacle" (albeit unintentionally), Charles Willie's conference was a spectacle as well-one that elicited an apology from Harvard and at least one of the original authors (Edelman, 1988; Oriard, 1993; Rayboy \& Dagenais, 1992). ${ }^{26}$ Moreover, it led to solid research on Black colleges.

Lastly, whereas it is reasonable (and accurate) to say that slavery was a damaging event, applying the idea of "Blacks as mere victims" as a blanket framework of interpretation today tends to obscure the agency of Blacks on their own behalf. Merely looking for the effects of slaverysuch as Uncle Tomism, aping White culture, internalized racism, etc.also exonerates White racists after slavery. This framework led Jencks and Riesman to miss precisely the developments that would later cast doubt on their research: growing Black assertiveness and self-awareness in the 1960s, which provided a foundation for the continuation and transformation of Black colleges today.

\section{Endnotes}

\footnotetext{
${ }^{1}$ The sense of betrayal was felt by those members of the Black college community that cooperated with Jencks and Riesman and then felt that they were misrepresented.

${ }^{2}$ Although not specifically focused on Black colleges, Abraham Flexner conducted a study entitled Medical Education in the United States and Canada, which literally provided the plan to eliminate all but two of the Black medical schools. Within several years of Flexner's Carnegie-sponsored report, only Meharry and Howard medical schools remained (Bonner, 2002; Flexner, 1910).
} 
${ }^{3}$ The location of conservative and non-confrontational was moved in this quote so that it would make sense in the paragraph. I did not however, change the meaning of Thompson's words.

${ }^{4}$ The process of accepting articles at Harvard Educational Review involves the board as a whole voting on the articles to be published. Then, the articles are assigned to two coeditors, who manage the content and process of one specific journal.

${ }^{5}$ David Riesman reiterated this idea in 1993.

${ }^{6}$ Please note that Jencks and Riesman were critical of many small White colleges as well, but these colleges were not used as comparison in the "The American Negro College" article. Jencks and Riesman's critique was published in an individual chapter ("anti-university colleges") of the Academic Revolution.

${ }^{7}$ Although Jencks and Riesman did justice to their discussion of the political and economic situation for African Americans during the Jim Crow era, they were not familiar with the specific plight of Black colleges.

${ }^{8}$ In the case of Daniel P. Moynihan, a report that might have been well meaning was dangerous to the African American community and served to undermine the structure of the African American family. Not only did Moynihan's work blame the victim rather than the oppressor for the Black families in situations of poverty, it also vilified Black women and pitted them against Black men. If Moynihan had consulted members of African American families and been familiar with African American history and culture, he might have created a richer study that was less susceptible to misinterpretation and misuse. In addition, his research might have been not only more accurate but also more useful to the very community he claimed to want to help. Also, note that defenders of Moynihan had alluded to his use of E. Franklin Frazier's work on the Black family to draw his conclusions. Although this claim is correct, it does not excuse Moynihan's actions.

${ }^{9}$ In 1943, in response to the critical fundraising situation for Black colleges, Tuskegee president Frederick D. Patterson crafted the idea of a united appeal for private Black colleges carried out by an organization specifically created for fundraising. Patterson sought to push giving in a new direction by reaching out to the average citizen rather than by focusing exclusively on a small number of wealthy donors. The goal of the Fund was to prevent the duplication of solicitations and to find new sources of funding from individual donors. On April 25, 1944, he established the United Negro College Fund with 27 member colleges and a combined enrollment of 14,000 students (Gasman, 2003a, 2003b; Gasman \& Epstein, 2004; Tucker, 2002; Williams, 1978).

${ }^{10}$ Christopher Jencks is a professor of social policy at Harvard University. From 1961-1963, Jencks served as an editor of the New Republic and then from 1963-1967, he was a fellow the Institute for Policy Studies in Washington. Shortly after authoring the Harvard Educational Review article, Jencks took a post at Northwestern University. His research pertains to economic inequality, inherited economic advantages, welfare reform, the homeless, and standardized testing. In addition to The Academic Revolution, Jencks has published several other books including The Homeless and The Black White Test Score Gap (with Meredith Phillips). A cold war era sociologist, David Riesman died at age 92 in 2002. A lawyer by training, Riesman taught at Harvard University for most of his career. Along with Reuel Denney and Nathan Glazer, he published a best-selling book, The Lonely Crowd, which was a "condemnation of consumerist passivity." Riesman also wrote Constraint and Variety in American Education (1956).

${ }^{11}$ Between 1965 and 1968, Time magazine's covers and lead stories focused on racial tensions in the United States and abroad. Story topics ranged from Black soldiers in Vietnam to leaders of the Black power movement to coverage of more mainstream organizations like the National Urban League.

${ }^{12}$ The Jencks and Riesman coverage was not a cover story, but merely a small insert in the magazine. For sample cover stories, see Time magazine 1966-1968.

${ }^{13}$ Wright to Heiskell, April 4, 1967, UNCF papers. Jencks and Riesman would proba- 
bly agree with Wright's comments, however, they did not spend adequate time addressing this within the article.

${ }^{14}$ Stephen Wright contacted the editor of the Harvard Educational Review and asked if the journal would publish a rebuttal to the provocative article. The editors, Davenport Plumer and Janet J. Sanfillipo, agreed to publish the UNCF-led response in its entirety. Harvard Educational Review dedicated 14 pages to the Black response, asked Jencks and Riesman to comment on the response, and also included 8 pages of letters to the editor on the topic. (More than one page of letters on any issue was unusual.)

${ }^{15}$ Dent describes the segregated high schools as inadequate and points to unequal funding, poor laboratories, crumbling libraries, overcrowding, and teachers with little or no training.

${ }^{16}$ Elias Blake, Jr., eventually became the president of Clark College in Atlanta and held this position from 1977 to 1987 . He was also an expert witness in the Fordice case in Mississippi (1992) that sought to desegregate Mississippi's public universities.

${ }^{17}$ The presidents of private Black colleges were particularly activist. They were not under the thumb of Southern legislatures and thus were more able to assist their students in civil rights efforts. For a deeper exploration, see Williamson (2003).

${ }^{18}$ Even some modern day critics such as film director Spike Lee (School Daze) have called into question the Black college students' attraction to Greek life, societal trappings, and the hazing process.

${ }^{19}$ It is important to note that Jencks and Riesman did make some changes to their article when it appeared in The Academic Revolution. These changes were based on criticism from the Black community.

${ }^{20}$ See E. Franklin Frazier, Black Bourgeoisie. In this text, Frazier was extremely critical of the Black middle class, pointing to their wearing of furs, socializing, and elite group membership as aiding the downfall of the race. As a result, he was ostracized by some members of the Black community.

${ }^{21}$ Martin Luther King, Jr., was assassinated on April 4. Earlier in the year and prior to that, riots exploded during what were intended to be peaceful marches led by Black leaders.

${ }^{22}$ Like Monro, A. J. Jaffe, Walter Adams, and Sandra G. Meyers published a study on the diversity among Black colleges and between Black college students. Unfortunately, it also had limited impact. These researchers from the Bureau of Applied Social Research at Columbia University completed their 1968 study of Black colleges in cooperation with Stephen J. Wright of the UNCF. Although their study was not entirely supportive of sustaining the "poorest" Black colleges, it was based on empirical data (using survey, census, and testing data). In addition, despite the prestigious institution from which its authors hailed, the tone of the essay was more encouraging than the tone adopted by Jencks and Riesman. It should be noted that in an earlier report, sponsored by the Bureau, the authors emphasized the need for this kind of empirical research rather than mere random observation, as in the case of the Jencks and Riesman article. See Jaffe, Adams, \& Meyers (1968a, 1968b).

${ }^{23}$ Charles V. Willie became aware of the impact of Jencks and Riesman article in 1974, when he took a faculty post at Harvard. Prior to this time, he was conducting sociological work on mental health at Syracuse University and had nothing to do with educational issues. Incensed and aligned with the other Black intellectuals at Harvard, in 1975 Willie began his challenge to Jencks and Riesman by teaching a course on the education contributions of Black colleges. He thought that the kinds of students coming to Harvard for degrees needed a sense of what a Black college was and what was happening at these institutions. (C. Willie, personal communication, September 2, 2003).

${ }^{24}$ Christopher Jencks did not attend the conference. By this date, he had moved on from Harvard to Northwestern University.

${ }^{25}$ In 1960 and 1962, Black scholars and administrators contributed to the conversations taking place about the status of Black colleges in an organized way. In 1960, The 
Journal of Negro Education published special issues on Black colleges entitled "The Negro Private and Church-Related College" and "The Negro Public College."

${ }^{26}$ The idea of the spectacle stems from Murray Edelman's notion of constructing the political spectacle. However, it has been adapted by those in media studies and communication to apply to the media's use of spectacle to enamor or distract an audience.

\section{References}

Allen, W. (1991). Colleges in Black and White: African American students in predominantly White and historically Black public universities. New York: State University of New York Press.

The American Negro college. (1967, March 31). Time, 64.

The American Negro colleges-four responses and a reply. (1967). Harvard Educational Review, 37(3), 451-468.

Anderson, J. D. (1988). The education of Blacks in the South. Chapel Hill, NC: The University of North Carolina.

Basinger, J. (2003, April 17). President resigns at beleaguered Morris Brown College. The Chronicle of Higher Education. Retrieved from http://www.chronicle.com.

Blake, E., Jr. (1967). Letter to the editors. Harvard Educational Review, 37(3), 472-473.

Bonner, T. (2002). Iconoclast: Abraham Flexner and a life in learning. Baltimore, MD: The Johns Hopkins University Press.

Bowles, F., \& DeCosta, F. A. (1971). Between two worlds. A profile of Negro higher education. New York: McGraw-Hill.

Browning, J. E. S., \& Williams, J. B. (1978). History and goals of Black institutions of higher learning. In C. Willie \& R. Edmonds (Eds.). (1978). Black colleges in America. Challenge, development, survival. New York: Teachers College Press.

Carson, C. (1981). In struggle: SNCC and the Black awakening of the 1960s. Cambridge, MA: Harvard University Press.

Coleman, J. S. (1966). Equity and educational opportunity. Washington, DC: Department of Health, Education, and Welfare.

Dent, A. W. (1967). "The American Negro college" four responses and a reply. Harvard Educational Review 37(3), 461-464.

Drewry, H. N., \& Doermann, H. (2001). Private Black colleges and their students. Princeton: Princeton University Press.

Du Bois, W. E. B. (1910). The college bred Negro American. Atlanta, GA: Atlanta University Publications.

Edelman, M. (1988). Constructing the political spectacle. Chicago: The University of Chicago Press.

Flexner, A. (1910). Medical education in the United States and Canada. Carnegie Foundation Bulletin, No. 4. New York: Carnegie Foundation.

Frazier, E. F. (1957). Black bourgeoisie. New York: The Free Press.

Freeman, K. (1998). African American culture and heritage in higher education research and practice. Westport, CT: Greenwood.

Gasman, M. (2003a). Rhetoric vs. reality: The fundraising messages of the United Negro College Fund in the immediate aftermath of the Brown decision. History of Education Quarterly, 44(1), 70-94. 
Gasman, M. (2003b). A word for every occasion: John D. Rockefeller, Jr. and the United Negro College Fund, 1944-1960. History of Higher Education Annual, 67-90.

Gasman, M., \& Epstein, E. (2004). Creating an image for Black higher education: A visual examination of the United Negro College Fund's publicity, 1944-1960. Educational Foundations, 18(2), 41-61.

Gilpin, P. J., \& Gasman, M. (2003). Charles S. Johnson. Leadership beyond the veil in the age of Jim Crow. New York: SUNY Press.

Gloster, H. M. (1967). "The American Negro college" four responses and a reply. Harvard Educational Review 37(3), 458-461.

Gurin, P. (1966). Social class constraints on the occupational aspirations of students attending some predominantly Negro colleges. The Journal of Negro Education, 35(4), $336-350$.

Gurin, P., \& Epps, E. (1966). Some characteristics of students from poverty backgrounds attending predominantly Negro colleges in the Deep South. Social Forces, 45(1), 27-40.

Gurin, P., \& Epps, E. G. (1975). Black consciousness, identity, and achievement: A study of students in historically Black colleges. New York: John Wiley \& Sons.

Integrating the Negro college. (1966, January 18). The New York Times, n.p.

Jaffe, A. J., Adams, W., \& Meyers, S. G. (1968a). Negro higher education in the 1960's. New York: Frederick A. Praeger.

Jaffe, A. J., Adams, W., \& Meyers, S. G. (1968b). The sharply stratified world of the Negro colleges (Publication no. A-482). New York: Columbia University Bureau of Applied Social Research.

Jencks, C., \& Riesman, D. (1967a). The American Negro college. Harvard Educational Review 37(2), 3-60.

Jencks, C., \& Riesman, D. (1967b). Four responses and a reply. Harvard Educational Review 37(3), 465-468.

Jencks, C., \& Riesman, D. (1968). The academic revolution. Chicago: University of Chicago Press.

John, W. C. (1920). Agricultural and mechanical colleges, 1917-1918. Washington, DC: U.S. Government Printing Office.

Jones, L. T. (1967, April 14). Letter to the editor. Time, 21.

Jones, T. J. (1969). Negro education: A study of the private and public higher education schools for colored people in the United States. New York: Arno Press.

June, A. W. (2002, October 18). Morris Brown College faces big debt and an accreditor's judgment. The Chronicle of Higher Education 49(8), A31.

Klein, A. (1969). Survey of Negro colleges and universities. New York: Negro Universities Press.

Levine, L. W. (1978). Black culture and Black consciousness: Afro-American folk thought from slavery to freedom. New York: Oxford University Press.

Mays, B. E. (1966, February). The achievements of the Negro colleges. The Atlantic Monthly, n.p.

Mays, B. E. (1967). "The American Negro college" four responses and a reply. Harvard Educational Review 37(3), 455-457. 
Mays, B. (1987). Interview conducted by Marcia Goodson, no. 1331, Columbia University Oral History Collection, Columbia University, New York.

Mays, B. E. (2003). Born to rebel. Athens, GA: University of Georgia.

McGrath, E. J. (1965). The predominantly Negro colleges and universities in transition. New York: Institute of Higher Education, Teachers College, Columbia University.

Morris, A. (1984). Origins of the Civil Rights Movement: Black communities organizing for change. New York: Free Press.

Moynihan, D. P. (1965). The Negro family: The case for national action. Washington, DC: U.S. Department of Labor.

The Negro college pleas for donations. (1966, January 21). The New York Times, n.p.

Negro colleges recruit Whites. (1966, January 16). The New York Times, n.p.

Negro colleges-their outlook. (1968, June 3). U.S. News and World Report, p. 74-78.

The Negro private and church-related college [Special issue]. (1960). The Journal of Negro Education, 29(3).

The Negro public college. (1962) The Journal of Negro Education, 31(3).

The new Black presidents. (1968, December 27). Time, n.p.

Oriard, M. (1993). Reading football: How the popular press created an American spectacle. Chapel Hill, NC: University of North Carolina.

Phelps-Stokes Foundation. (1932). The twenty-year report of the Phelps-Stokes Fund, 1911-1931. New York: Author.

Pipkin, S. B. (1967, April 14) Letter to the editor. Time, 19-21.

Poe, J. (2002, November 14). Black colleges under pressure to change, close. Atlanta Journal Constitution, A1, F1.

Rayboy, M., \& Dagenais, B. (Eds.). (1992). Media, crisis, and democracy: Mass communication and the disruption of social order. London: Sage.

Rooks, C. S. (1967, April 14 ). Letter to the editor. Time, 19.

Schexnider, A. J. (2003) Will private Black colleges survive in the twenty-first century? The Journal of Blacks in Higher Education, 128-130.

Sekora, J. (1968). On Negro colleges: A reply to Jencks and Riesman. Antioch Review, $28(1), 5-26$.

Simmons, K. (2002, October 6). Morris Brown at the brink. Atlanta Journal Constitution, Metro Section, C2, C4, C5.

Sowell, T. (2003a, October 3). On racial censorship and Rush Limbaugh. Jewish World Review. Retrieved from http://www.jewishworldreview.com/cols/sowell1.asp.

Sowell, T. (2003b, October 7). Rush not guilty of overt racism. Lenawee Connection. Retrieved October 7, 2003, from http://www.lenconnect.com.

Stanley, J. C. (1967). Letter to the editors. Harvard Educational Review, 37(3), 469-476.

Stewart, C. F. (1999). Black spirituality and Black consciousness: Soul force, culture and freedom in the African American experience. New York: African World Press.

Stuckey, S. (1987). Slave culture. Nationalist theory and the foundations of Black America. New York: Oxford University Press.

Thelin, J. R., Casteen, III, J. T., \& Bailey, J. M. (1998). After the Academic Revolution: A retrospective forum. The Review of Higher Education, 12(1), 1-16. 


\section{The Journal of Higher Education}

Thompson, D. C. (1973). Private Black colleges at the crossroads. Westport, CT: Greenwood Press.

Tucker, S. K. (2002). The early years of the United Negro College Fund, 1943-1960. The Journal of African American History, 87, 416-432.

Urban, W. J. (1992). Black scholar. Athens, GA: University of Georgia Press. U. S. Office of Education. (1942). National survey of the higher education of Negroes. Washington, DC: U.S. Government Printing Office.

Whither higher education: The Jencks-Riesman view. (1968, May 20). The Chronicle of Higher Education, 8.

Williams, L. (1978). The United Negro College Fund: Its growth and development. Unpublished doctoral dissertation, Columbia University.

Williams, L. E. (1988). Public policies and financial exigencies. Black colleges twenty years later, 1965-1985. Journal of Black Studies, 19(2), 135-149.

Williamson, J. (2003). Student activists, activist students: Black colleges and the Civil Rights Movement. Paper presented at the History of Education Society Annual Meeting, Chicago, IL.

Willie, C. V., \& Edmonds, R. R. (1978). Black colleges in America: Challenge, development, survival. New York: Teachers College Press.

Wright, S. J. (1967a). "The American Negro college" four responses and a reply. Harvard Educational Review 37(3), 451-455.

Wright, S. J. (1967b). Letter to Andrew Heiskell, Chairman of the Board, Time Magazine, April 4, 1967, box 12, microfiche 1801, Atlanta University Center, Robert W. Woodruff Library, United Negro College Fund Papers, Atlanta, GA (UNCF Papers). 